\title{
Fisiografia da região do planalto de Poços de Caldas, MG/SP
}

\author{
Fernanda Tonizza Moraes ${ }^{1}$ \& Jairo Roberto Jiménez-Rueda ${ }^{2}$
}

\begin{abstract}
Resumo A análise fisiográfica tem por princípio o entendimento das condições de gênese e evolução das paisagens que apresentam estreita associação com os processos pedogênicos, o que possibilita o reconhecimento dos tipos de solos associados a cada paisagem, sendo de grande auxílio na execução de programas de zoneamento geoambiental. Este trabalho apresenta a análise fisiográfica realizada a partir de fotointerpretação de imagens orbitais e o estabelecimento dos aspectos morfogenéticos, altimetria e dissecação do terreno, utilizando-se como estudo de caso a região do planalto de Poços de Caldas, MG. Nesta área pode-se definir a ocorrência de paisagens planálticas associadas a solos regolíticos e concrecionários coluviais originados a partir de materiais alóctones em um relevo policíclico. As paisagens aluviais apresentam volumes gleicos e materiais orgânicos soterrados.
\end{abstract}

Palavras-chave: análise fisiografia, pedogênese, zoneamento geoambiental.

\begin{abstract}
Physiography of the Poços de Caldas plateau's region, MG/SP, Brazil. The physiographic analysis statement is that the understanding of origin and evolution of the landscape can provide the soil's occurrence and characteristics, which are very important in geoenvironmental zoning programs. This paper presents a physiographic analysis based on remote sensing, morphogenetical aspects, altitude and dissecation to decide upon the phisiography of the land. The study was developed in Poços de Caldas's volcanic alkaline plateau between Minas Gerais and São Paulo states. In this area there are some plateaus associated with regolithic soils generated from allochthonous materials. These landscapes were formed by recurrent processes of erosion and neotectonic uplift. The alluvium plains present gleisoils and buried organic matter.
\end{abstract}

Keywords: physiographical analysis, pedogenesis, geoenvironmental zoning.

INTRODUÇÃO A fisiografia trata da análise da paisagem e da descrição de sua gênese e evolução através dos solos existentes, considerando o solo e as coberturas de alteração intempérica como registros e testemunhos dos eventos geológicos, geomorfológicos e climáticos ao longo do tempo (Botero 1978, Goosen 1971 e Villota 1992 e 2005).

O princípio básico da análise fisiográfica é a existência de uma relação direta entre as propriedades externas de uma paisagem e suas características internas, expressas nos perfis de solos. Cada unidade fisiográfica apresenta uma fisionomia reconhecível e diferenciável das adjacentes e delimita uma porção da superfície terrestre com uma morfogênese específica na qual se espera certa homogeneidade pedológica (Souza \& Jiménez-Rueda 2007, Barbosa et al. 2005).

Goosen (1967) considera fisiografia como geografia de solos por tratar do estudo das características externas das paisagens e a sua influência nas características internas ou pedológicas (Villota 2005), de modo que o reconhecimento das paisagens possa revelar os padrões de ocorrência de solos.

Neste contexto, a realização da análise fisiográfica presta grande auxílio aos programas de zoneamento geoambiental, pois a partir desta pode-se estabelecer e definir a ocorrência dos grandes processos pedogenéticos, facilitando a compartimentação do terreno e a compreensão de suas características, bem como avaliar as condições de suporte às ações antrópicas, que são os objetivos finais dos programas de zoneamento. A análise fisiográfica é realizada com o intuito de facilitar o reconhecimento dos padrões de ocorrência dos solos, bem como fornecer informações referentes às condições e evolução da paisagem, sendo, portanto, indispensável para atividades de zoneamento geoambiental.

Este estudo apresenta uma metodologia de análise fisiográfica adotada pela equipe de Zoneamento Geoambiental da UNESP - Rio Claro, tendo-se como estudo de caso a região do Planalto de Poços de Caldas, na divisa entre Minas Gerais e São Paulo.

ÁREA DE ESTUDO Localiza-se na divisa dos estados de Minas Gerais e São Paulo, conforme exposto na figura 1. Na imagem, foram incluídos os limites políticos dos municípios inseridos na área de estudo.

O maciço de Poços de Caldas caracteriza-se pela presença de uma caldeira vulcânica principal, quase completa, resultante da intrusão de rochas alcalinas durante o Cretáceo Superior (Ellert 1959), datada de aproximadamente 72,4 Ma segundo Thomaz Filho e

1- Programa de pós-graduação em Geociências e Meio Ambiente, Instituto de Geociências e Ciências Exatas, Universidade Estadual Paulista, Campus de Rio Claro, Rio Claro (SP), Brasil. E-mail: fetonizza@hotmail.com

2- Departamento de Petrologia e Metalogenia, Instituto de Geociências e Ciências Exatas, Universidade Estadual Paulista, Campus de Rio Claro, Rio Claro (SP), Brasil. E-mail: jairorjr@rc.unesp.br 


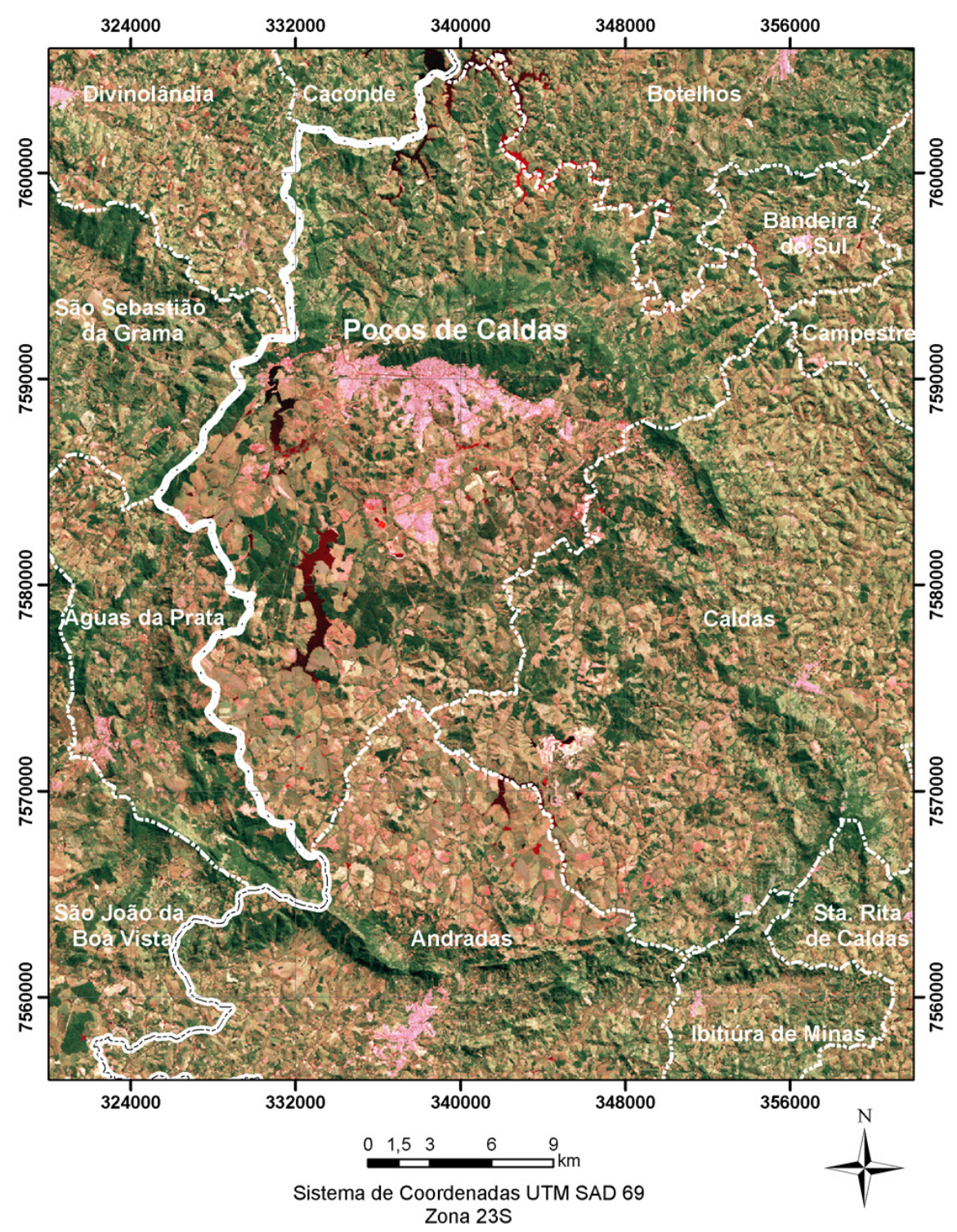

Figura 1 - Localização e limites dos municípios na área de estudo.

Rodrigues (1999), isto é, no Campaniano. A estrutura interna do complexo foi determinada pelo padrão de estruturas circulares menores (subcaldeiras) que foram truncadas umas pelas outras de acordo com suas idades relativas (Almeida-Filho \& Paradella 1977).

Segundo Valeton et al. (1997) predominam as rochas plutônicas de granulação fina e rochas do grupo das nefelina-sienitos leucocráticas subvulcânicas (tinguaíto), incluindo rochas enriquecidas por potássio, que cobrem $78 \%$ da superfície da área anelar. Sienitos de granulação média ocupam $13,5 \%$, fonolitos $5 \%$ e rochas piroclásticas $3 \%$. Outros tipos de nefelina sienitos perfazem $0,5 \%$, sendo o lujaurito e chibinito (Fig. 2).

A intrusão ocorreu em domínios do embasamento cristalino, sendo a caldeira cercada por granitos, gnaisses e migmatitos de alto grau metamórfico, policíclicas e polideformadas pertencentes ao Maciço de Guaxupé. O Maciço de Guaxupé é limitado pelos cinturões de cisalhamento Campo do Meio (direção WNW-ESE) e Ouro Fino (direção ENE-WSW) (Melo et al. 1993).

A análise do mapa morfoestrutural e dos principais lineamentos, que determinam a ocorrência de trends de fraturas (Fig. 3) demonstra que a área foi intensamente afetada por eventos tectônicos. As direções predominantes dos lineamentos estão entre NW-SE e NE-SW. A ocorrência de direções próximas a N30E e N30W é coincidente com a orientação de duas das inúmeras intrusões alcalinas que cortaram o sul do Brasil (Ellert 1959).

A ocorrência da intrusão alcalina e seu posterior abatimento devido ao intenso falhamento conforme originalmente proposto por Ellert (1959) e modificado por Schorscher \& Shea (1991) definiu a instalação de antiformes e sinformes de menor extensão no interior e nas adjacências da cratera. A presença de altos e baixos estruturais deve-se respectivamente ao soerguimento e abatimento de blocos.

A evolução da paisagem do planalto deve-se em grande parte a estas atividades ocorridas após a ati- 


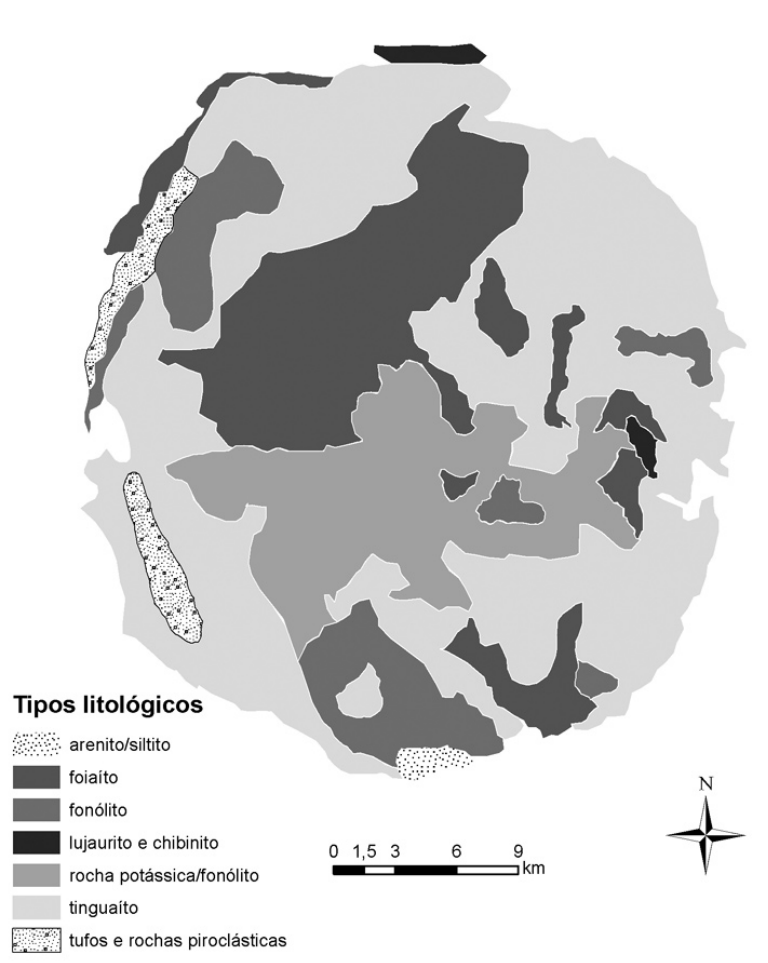

Figura 2 - Representação esquemática da localização dos tipos litológicos no maciço alcalino de Poços de Caldas. O entorno é composto por rochas do embasamento cristalino. Modificado de Ellert (1959).

vidade magmática que ocasionou a formação da caldeira alcalina, incluindo atividades tectônicas recentes (Schorscher \& Shea 1991).

Estes são os principais eventos que definem o arranjo morfoestrutural da área de estudo. Os blocos que foram elevados e rebaixados na parte interna do planalto comportam-se como altos e baixos estruturais de menor extensão, que associados ao relevo determinam fisiografias variadas.

Altos e baixos estruturais apresentam comportamentos distintos quanto às reações intempéricas e processos geoquímicos, definindo condições heterogêneas para a pedogênese. Em altos estruturais, predominam os processos de laterização e/ou oxidação inten$\mathrm{sa}$, resultando em um lavado mais eficiente do solo e a formação de óxidos/hidróxidos de ferro, alumínio e titânio. Nos baixos, o impedimento à drenagem que a própria estrutura rochosa impõe, define um ambiente relativamente redutor, um lavado menos eficiente pelas soluções intempéricas e a formação de argilas do grupo das ilitas, esmectitas e montmorillionitas (Fassbender 1975, Jiménez-Rueda et al. 1993).

Quanto à geomorfologia, o maciço alcalino está inserido nos domínios do Planalto Atlântico, apresentando forma ligeiramente elíptica com eixo maior de 35 quilômetros no sentido NE-SW e o menor de 30 quilômetros no sentido NW-SE. O dique anelar é saliente na topografia em três quadrantes: norte, oeste e sul. No quadrante leste, não há expressão morfológica do anel de tinguaíto
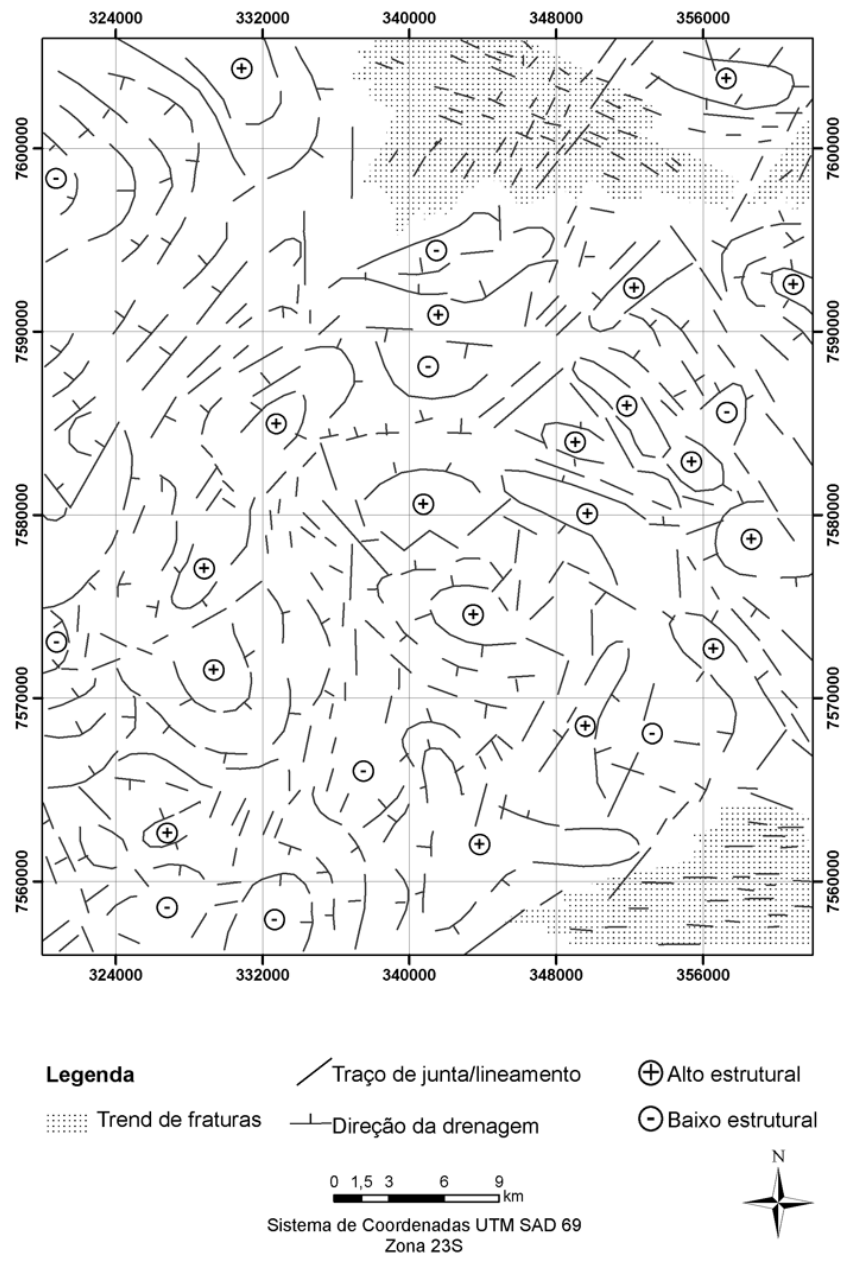

$\oplus$ Alto estrutural

Baixo estrutural

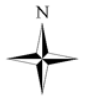

Figura 3 - Mapa morfoestrutural e lineamentos estruturais da área de estudo.

(Cavalcante et al. 1977, Christofoletti 1973).

A área apresenta clima mesotérmico, sendo predominante o tipo $\mathrm{Cwb}$, havendo porções localizadas a norte e oeste com clima do tipo Cwa (Cavalcante et al. 1977, Setzer 1956).

A vegetação florestal predominante na área pode ser classificada segundo Rizzini (1979) como floresta pluvial de altitude, podendo ser denominada de Floresta Atlântica. No interior do maciço alcalino predominam os campos nativos.

MATERIAL E MÉTODOS Para a definição da metodologia de análise fisiográfica, tomaram-se por base os trabalhos desenvolvidos por Goosen (1971), Villota (2005), Barbosa et al. (2005) que seguem a metodologia proposta pelo CIAF (Centro Interamericano de Fotointerpretación). O CIAF é um órgão do governo colombiano em parceria com o governo holandês e a OEA (Organização dos Estados Americanos) que oferece treinamento e educação avançada na utilização de imagens aéreas, tendo sido criado em 1967 (IGAC 2007).

A metodologia de análise fisiográfica apresentada considera que as unidades de paisagem podem ser classificadas basicamente em função do processo mor- 
fogenético, altimetria e grau de dissecação.

Para o ajuste ou a elaboração de documentos de suporte técnico, tais como documentos cartográficos, foram utilizadas imagens de satélite LANDSAT 5 TM (órbita 219, ponto 75; data de passagem: 03 de maio de 2004, bandas disponíveis de 1 a 7) para a confecção de composições coloridas que se adequassem à melhor visualização dos alvos.

Todas as operações para constituição do banco de dados, bem como as análises das imagens para elaboração das cartas temáticas foram realizadas através do aplicativo SPRING 4.3.3 (Camara et al. 1996). Para que integrassem o banco de dados, as imagens foram registradas (georreferenciadas) com a utilização de cartas topográficas em escala 1:50.000 (IBGE 1972).

Após o registro, executou-se o processamento das imagens a partir das opções de contraste fornecidas pelo aplicativo Spring. O contraste linear foi utilizado como padrão e algumas bandas foram submetidas a outros processamentos, como a equalização do histograma e raiz quadrada. As bandas $5(1,55$ a $1,75 \mu \mathrm{m})$ e 7 $(2,08$ a $2,35 \mu \mathrm{m})$ foram mais utilizadas para as análises por exibirem com maior qualidade a expressão superficial das feições geológicas.

As fraturas e os traços de juntas foram digitalizados a partir da imagem de satélite diretamente no aplicativo SPRING, sendo representados por feições lineares estabelecidas pela menor unidade retilínea que se repete por toda a imagem. O mapa de fraturas é apresentado na figura 4.

Foram estabelecidas três classes de dissecação em função da densidade de lineamentos estruturais ou traços de juntas. A premissa para esta análise é considerar estes fraturamentos como descontinuidades que representam partições no terreno, definindo locais de maior permeabilidade pela concentração do escoamento da drenagem. Para o estabelecimento destas classes, analisaram-se visualmente cada uma das unidades fisiográficas delimitadas por fotointerpretação (Fig. 5). Através da análise visual da densidade de partições, pode-se estabelecer as seguintes classes: 1 - levemente dissecado, 2 - moderadamente dissecado, 3 - fortemente dissecado (Mattos et al. 2002).

Para proceder à análise altimétrica, utilizou-se o aplicativo Global Mapper (2005) gerando-se as curvas de nível eqüidistantes de $20 \mathrm{~m}$. As imagens para esta análise foram obtidas através do projeto Brasil em Relevo da Embrapa (Miranda 2005). Estas curvas foram salvas em formato shape e importadas pelo aplicativo SPRING para compor o banco de dados. A partir das curvas de nível, gerou-se uma grade regular e procedeu-se ao fatiamento com passo de 100 metros.

Devido a grande amplitude altimétrica existente na área de estudo (Fig. 6), os planaltos puderam ser divididos em cinco categorias altimétricas: muito baixos (800$900 \mathrm{~m})$, baixos (900-1000m), médios (1000-1200m), altos (1200-1400m), muito altos (acima de 1400m).

Paralelamente à elaboração dos mapas altimétrico e de fraturas, passou-se à classificação e organização das paisagens pela fotointerpretação de imagens
LANDSAT 5 TM, buscando-se delimitar os diferentes padrões de cor e textura, utilizando-se o método clássico de fotointerpretação (Goosen 1967, Soares \& Fiori 1976, Veneziani \& Anjos 1982). Durante o processo de fotointerpretação, utilizou-se inicialmente escala próxima a 1:200.000 para delimitar os níveis planálticos e distinguir os principais padrões texturais.

Posteriormente, para ajuste dos limites entre as unidades fisiográficas e a demarcação dos elementos da paisagem indicativos de processos fisiográficos (tais como terraços fluviais, canais abandonados, formas das vertentes, entre outros) utilizou-se uma escala de maior detalhamento, próxima a 1:50.000 e fotografias aéreas 1:25.000.

Em campo, procedeu-se ao diagnóstico dos registros pedoestratigráficos cuja metodologia e resultados são apresentados em detalhe em Moraes (2008) em cada uma das unidades fisiográficas destacadas pela fotointerpretação. Desta forma foi possível associar a fisiografia aos solos existentes.

RESULTADOS E DISCUSSÃO A análise dos principais processos morfogenéticos na área de estudo indica a ocorrência de dois grandes grupos de paisagens: as planálticas e as aluviais delimitadas na figura 7 .

As paisagens planálticas foram reconhecidas pela presença de taludes delimitando porções relativamente planificadas ou homogêneas da superfície mas que contém vestígios de unidades fisiográficas das planícies aluviais e dos colúvio-alúvios subatuais e recentes soerguidos: planaltos menores que puderam ser agrupados em função da altimetria, do grau de dissecação e da morfologia associada. As paisagens aluviais apresentam as planícies de inundação como unidades fisiográficas típicas, definidas pela presença de terraços fluviais, diques marginais, canais abandonados e lagoas marginais.

Para a classificação das paisagens planálticas utilizaram-se como critérios a altimetria e o nível de dissecação, definindo-se planaltos muito altos, altos, médios, baixos e muito baixos. Em alguns casos, foi possível associar estas unidades fisiográficas à ocorrência de morfologias bem definidas, como colinas em forma de meia-laranja ou alongadas.

Quanto aos processos pedogênicos, os planaltos são estruturas de origem tectônica resultantes do soerguimento de blocos que passam de formas agradacionais a degradacionais, dando início a um processo de geração de sedimentos de diferentes granulometrias. Estes sedimentos irão compor materiais concrecionários em perfis de solo localizados em planícies, em blocos que sofreram abatimento por ação tectônica ou mesmo em perfis de solo situados em porções rebaixadas no próprio planalto.

A análise da composição, forma, tamanho e freqüência de ocorrência de concreções oferece informações sobre a história evolutiva da paisagem planáltica, bem como pode ser utilizada para comprovar a natureza alóctone (não residual) dos materiais regolíticos que formam as diferentes paisagens e geram os diversos perfis de solo.

Em todos os níveis planálticos avaliados, esti- 


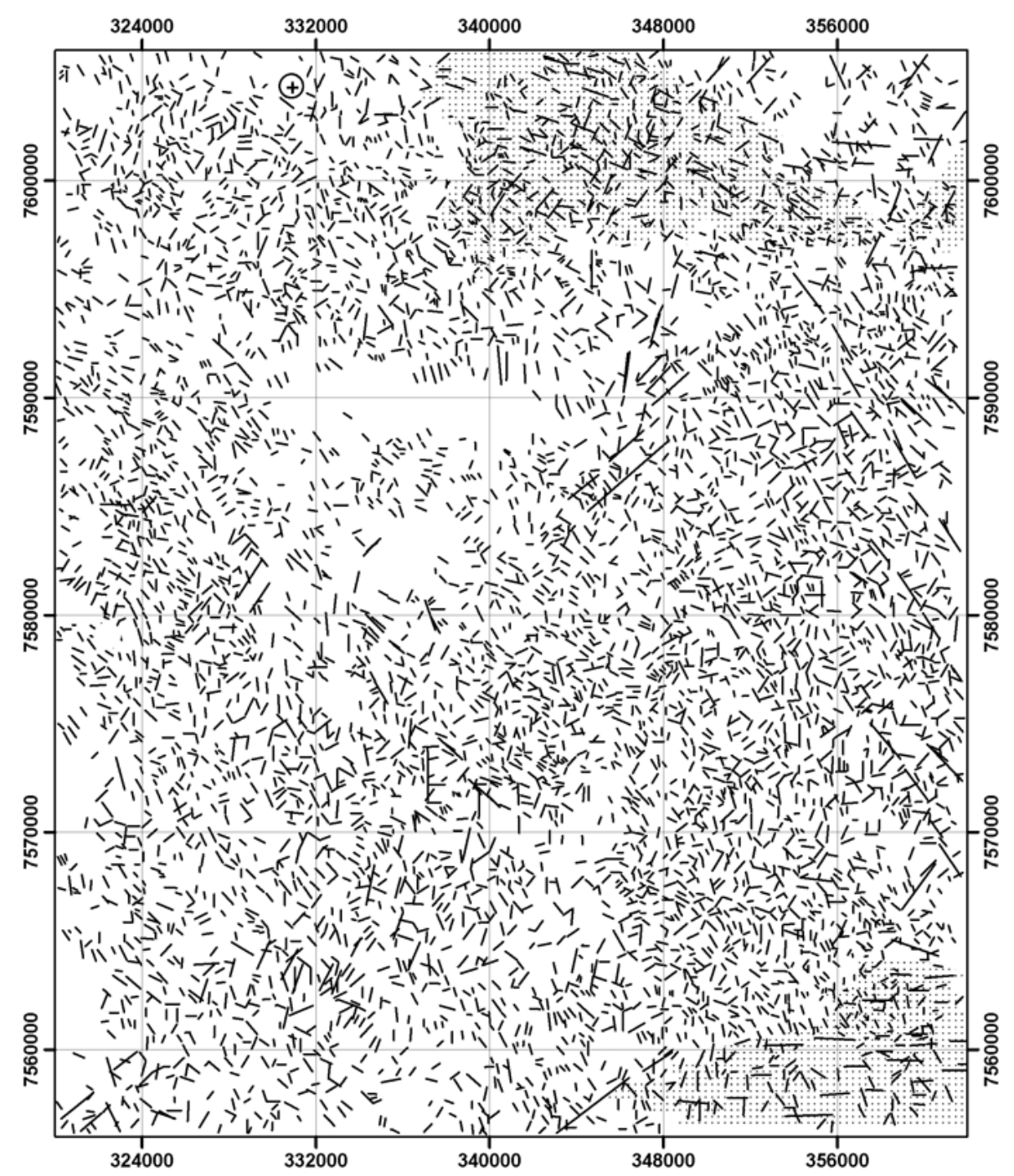

Legenda

Trend de fraturas
Fraturas/lineamentos
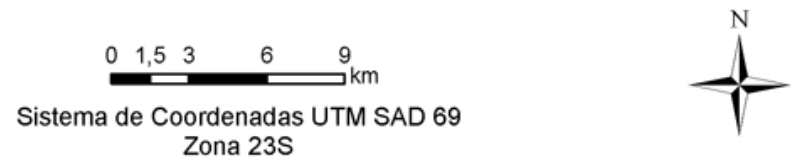

Figura 4 - Mapa de traços de juntas e fraturas.

veram presentes volumes concrecionários em diferentes posições e em diversas concentrações nos perfis de solo, por vezes aflorantes, por vezes soterrados por depósitos regolíticos mais recentes.

Para as paisagens aluviais, adotou-se a classificação em planície de inundação atual ou subatual. Estas paisagens são representadas por terraços, diques marginais, leitos abandonados, reconhecíveis à escala de fotointerpretação (de 1:25.000 a 1:100.000) e no campo, porém muitas vezes não destacáveis na escala de representação. As planícies subatuais correspondem atualmente a jovens planaltos. Nestas paisagens, a pre- sença de elementos como canais abandonados, depósitos de materiais aluvionais, lagoas marginais, depósitos de turfeiras e solos orgânicos constituem evidências geomorfológicas e pedológicas de campo que permitem associar a paisagem a um regime paleo-aluvial.

Paisagens Planálticas $\mathrm{O}$ início da história fisiográfica da área de estudo dá-se durante o Cretáceo Superior, com o processo de intrusão alcalina, definindo inicialmente a formação de paisagens montanhosas que extrapolavam os limites da área de estudo, estendendose aos domínios vulcânicos de Itatiaia e Passa Quatro. 


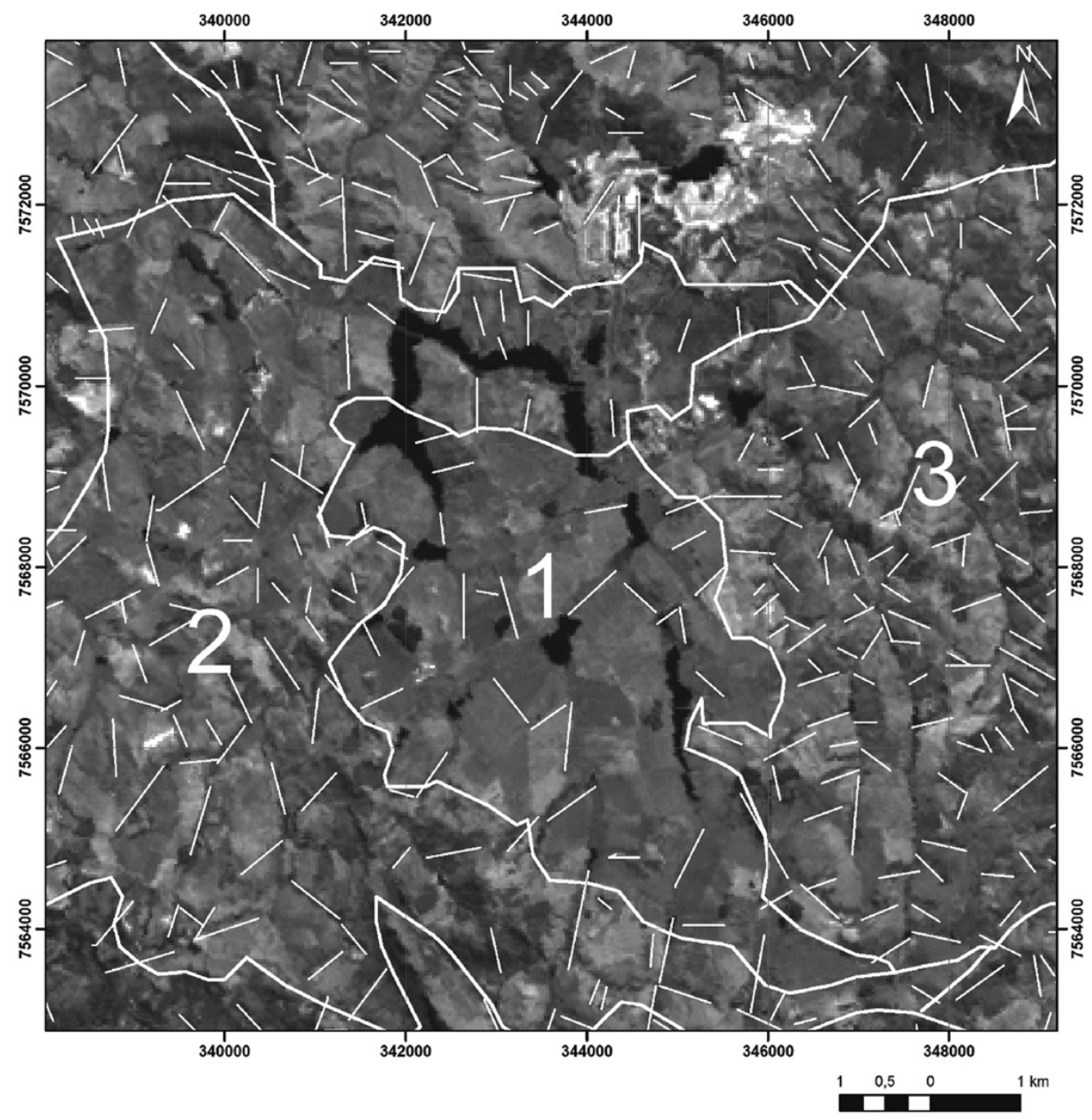

Figura 5 - Classes de dissecação do terreno definidas por critérios de fotointerpretação. 1: fracamente dissecado, 2: moderadamente dissecado, 3: fortemente dissecado.

Nesta etapa teve-se o predomínio de formas de relevo estruturais definidas pela ação do vulcanismo e tectônica (Ellert 1959, Theodorovicz et al. 2002, Suertegaray 2003). A modificação total ou parcial destas paisagens montanhosas em "Paisagens Planálticas" deve-se ao efeito progressivo dos processos morfodinâmicos degradacionais conduzidos pelas diferentes condições climáticas ao longo do tempo geológico, aliados aos processos morfotectônicos que geraram o soerguimento e o abatimento de blocos bem como a intensificação de fenômenos rúpteis e dúcteis.

As superfícies planálticas são superfícies erosivas provenientes da denudação de antigas planícies agradacionais (pediplanação) ou do aplainamento diferencial de antigas paisagens montanhosas (peneplanização), determinados por uma ação prolongada dos processos erosivos aliados a movimentos tectônicos modernos (Saadi 1998, Villota 2005). Estas superfícies aplainadas podem ser então soerguidas ou abatidas pela ação tectônica. $\mathrm{Na}$ área de estudo, a ação denudacional definiu a alternância entre topos de morros com diversos níveis de aplainamento e a formação de taludes com tamanho e inclinação variável.

As unidades fisiográficas de maior expressão nas paisagens planálticas são os planaltos e os taludes, sendo que os planaltos podem apresentar um topo com morfologia determinada pela presença de colinas em formato de meia-laranja ou colinas alongadas, o que remete ao embasamento litológico/estrutural e ao sistema morfotectônico. As colinas alongadas estão associadas a materiais metamórficos anisotrópicos como os gnaisses e os migmatitos, enquanto as colinas arredondadas associam-se ao intemperismo de granitóides e rochas alcalinas. Ocorrem também planaltos que não estão associados a nenhuma geoforma específica, por serem mais jovens ou por encontrar-se em regiões de maior estabilidade tectônica.

Planaltos Segundo Villota (2005), os planaltos são unidades genéticas de relevo de extensão regional que compreendem todo tipo de antigas terras planas que foram soerguidas, deixando de lado o comportamento agradacional que apresentavam anteriormente. $\mathrm{Na}$ área de estudo, os planaltos se encontram em diferentes altitudes, podendo apresentar coberturas/estratos horizontalizados formados por sedimentos e/ou materiais vulcânicos. As coberturas existentes nos planaltos vêm sendo submetidas, por diferentes períodos e mediante 


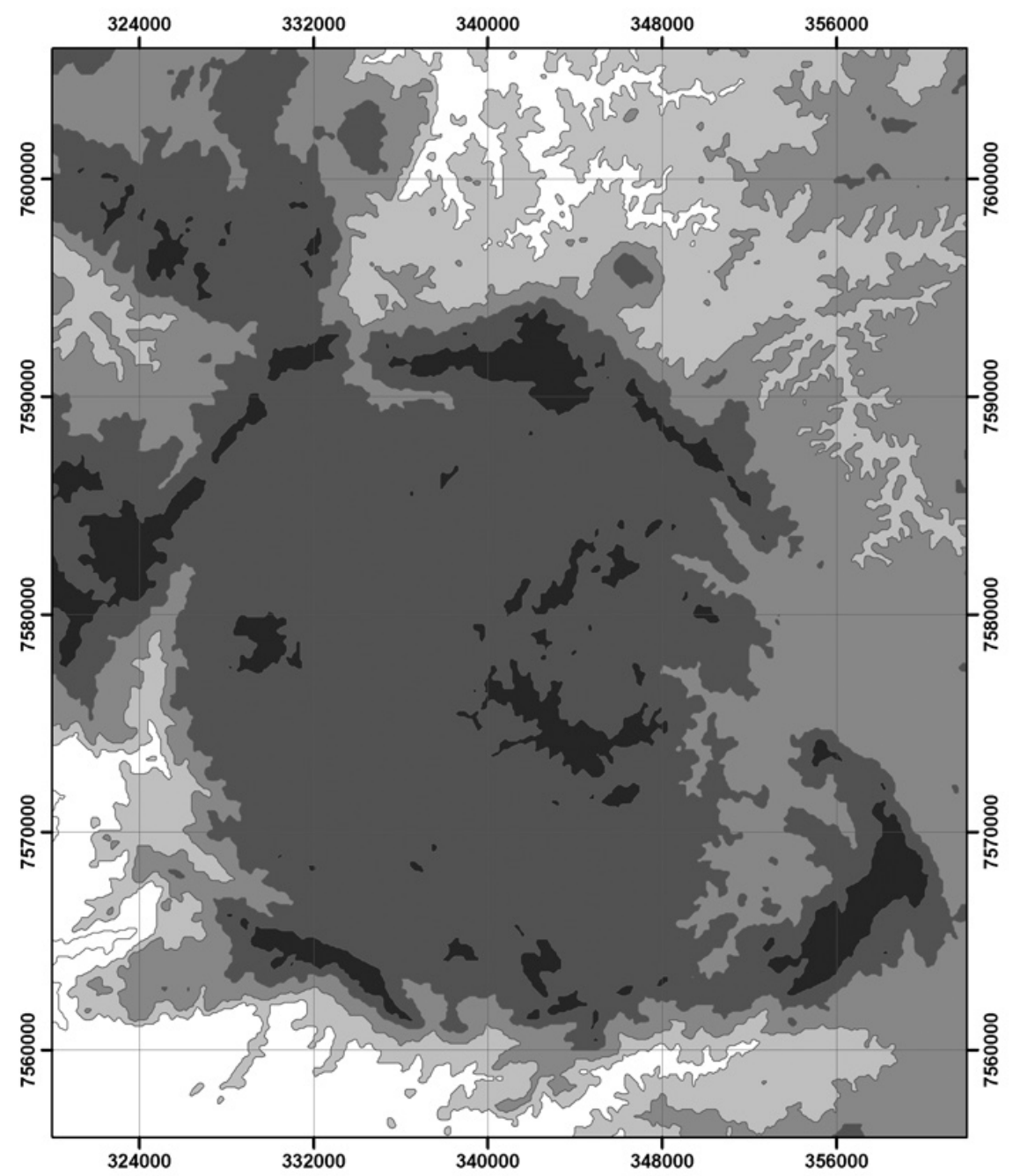

\section{Classes de altimetria ( $m$ )}

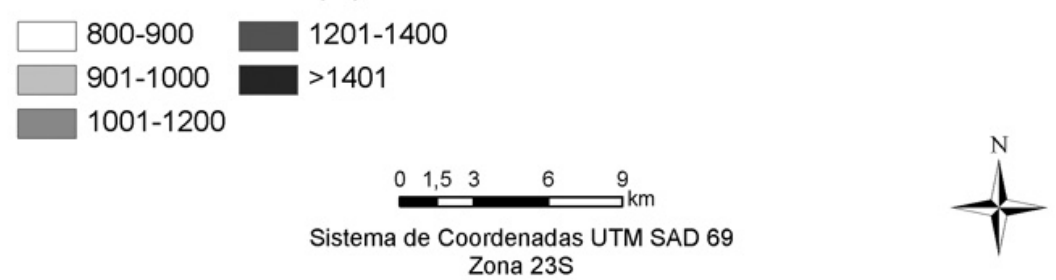

Figura 6 - Análise da variação altimétrica.

diferentes intensidades, ao ataque gradual de um conjunto de processos degradacionais, incluindo-se uma forte meteorização e desenvolvimento pedogenético. Posteriormente, a ação da erosão fluvial e algumas formas de remoção em massa, levam à transformação ainda maior de sua morfologia inicial.

A variação do nível de entalhamento da drenagem e a sua densidade correspondem ao grau de dissecação. Diferenças no nível de dissecação podem ser decorrentes da resistência litológica e ação tectônica e da incidência de climas úmidos ou secos sobre estas litologias, pois mesmo em litologias friáveis, a ausência de períodos úmidos define uma dissecação incipiente (Casseti 2007). Assim, quanto maior a umidade, a ins- tabilidade tectônica e a friabilidade do material rochoso, maior o grau de dissecação. A área de estudo apresenta três categorias de dissecação do terreno, definidas a partir de fotointerpretação e análise do conjunto/densidade e direção de fraturas:

- nível de dissecação 1: observado frequentemente nas áreas aluviais recentes e eventualmente nos maciços (escudos) rochosos imbricados. No caso de depósitos aluviais, a explicação para a baixa dissecação é que não houve tempo suficiente para que o material se adequasse à estrutura geológica do terreno, definida pelos sistemas de traços de juntas, fraturas e lineamentos estruturais. Porém, em áreas com maior atividade tectônica, a idade recente do depósito pode ser compen- 


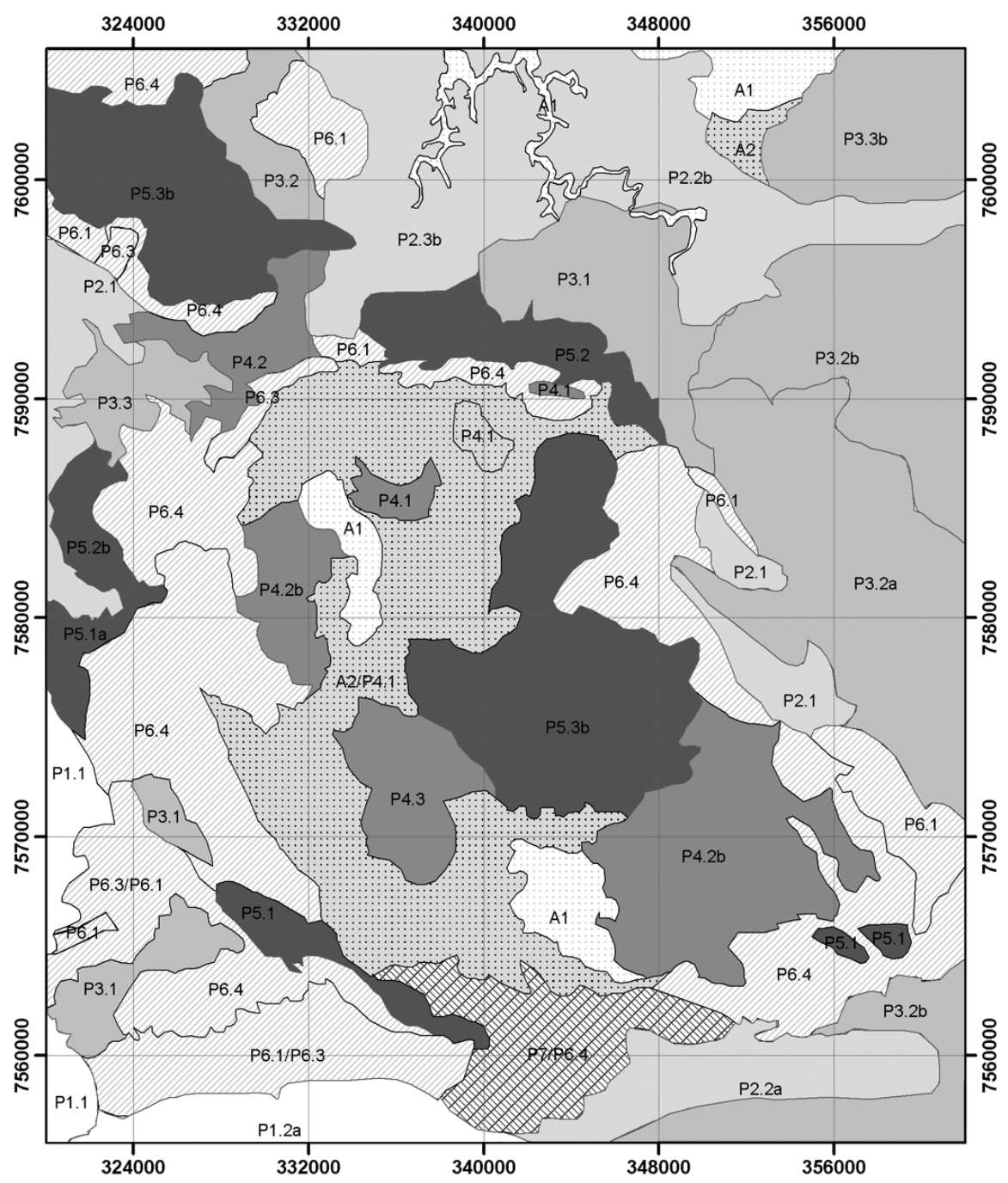

Paisagens planálticas $(P)$ e aluviais $(A)$

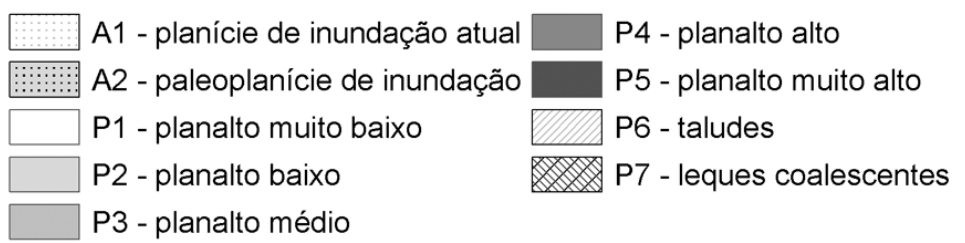

\section{Grau de dissecação dos planaltos (P1 a P5)}
.1 - levemente dissecado
.2 - moderadamente dissecado
.3 - fortemente dissecado

\section{Morfologia associada aos planaltos (P1 a P5) \\ a - colinas arredondadas \\ b - colinas alongadas}

\section{Morfologia associada aos taludes (P6)}

P6.1 - retilíneos

P6.3 - convexos
P6.2 - côncavos

P6.4 - mistos

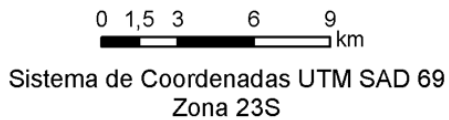

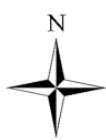

Figura 7 - Mapa de paisagens e unidades fisiográficas. 
sada, sendo possível que depósitos recentes assumam uma estruturação definida pelas condições morfotectônicas em um tempo reduzido. Estas considerações são resultado da adaptação dos conceitos de Tricart (1977) e Saadi (1998). Segundo os autores, a evolução das paisagens é uma conseqüência da ecodinâmica, expressa através do balanço entre morfogênese (em áreas instáveis tectonicamente) e pedogênese (nas áreas em que as condições tectônicas são mais estáveis).

- nível de dissecação 2: situação de dissecação intermediária, categoria mais freqüente na área de estudo.

- nível de dissecação 3: dissecação forte definida pela ação erosiva em terrenos com atividade tectônica mais intensa (morfogênese maior que pedogênese), litotipos friáveis ou a presença de solos antigos intensamente erodidos, o que remete à maior permeabilidade das rochas e define um sistema de partição (Mattos et al. 2002).

P1 - PLANALTOS MUITO BAIXOS (800-900M) Ocorrem na porção sul e sudoeste da área de estudo, estando inseridos no embasamento cristalino. Apresentam dissecação baixa a moderada, não havendo este tipo de planalto fortemente dissecado na área de estudo. Correspondem às paleoplanícies da Bacia Hidrográfica do Rio Mogi Guaçu, sendo, portanto, unidades fisiográficas que passaram de aluviais a planálticas. Registros do passado aluvial são os solos contendo grãos de quartzo e seixos alúvio-coluvionais com formato subarredondado a subangular indicando retrabalhamento e a ocorrência de canais abandonados, muito marcantes nas proximidades de Santo Antônio do Jardim. Estes canais abandonados possuem solos com evidência de processos hidromórficos, podendo estar recobertos por materiais coluvionais de granulometria milimétrica a centimétrica, indicando a mudança de processo na definição da paisagem, ou seja, a passagem de uma paisagem aluvial (agradacional) a uma paisagem planáltica (degradacional).

P2 - PLANALTOS BAIXOS (900-1000M) Ocorrem em terrenos cristalinos associados à Represa da Graminha, norte da área de estudo, em que apresentam colinas alongadas definidas por material gnáissico-migmatítico e níveis de dissecação que variam de moderado a forte. Sendo a morfoestrutura de baixo topográfico, há a formação de ambientes pedogênicos com tendência a ocorrência de ambientes redutores (formação de Goethita). Há ocorrência de materiais plinficados nas bases destes perfis, indicando tratarem-se de paleo-latossolizações. Porém, uma análise mais detalhada das camadas superficiais destes materiais demonstra a ocorrência de concreções com quartzo milimétricas, denotando a ocorrência de transporte de sedimentos alóctones e soterramento do perfil.

Já a leste da represa, predominam as colinas alongadas, porém a dissecação é moderada. A dissecação obedece ao sentido preferencial de orientação dos lineamentos estruturais (NW), Indicando a infuência da tectônica recente/atual na definição da morfogênese.

A sudoeste, leste e sudeste, ocorrem pequenos planaltos baixos em terrenos cristalinos. A presença de colinas em forma de meia-laranja é devido ao domínio granítico e ao sistema tensor com traços de juntas que assumem um traçado perpendicular. O nível de dissecação varia de fraco a moderado.

A noroeste ocorre um planalto baixo adjacente aos taludes que delimitam o planalto de Divinolândia (planalto muito alto). Este planalto baixo apresenta dissecação fraca e comporta-se como uma planície agradacional por receber sedimentos coluvionares provenientes do planalto muito alto adjacente. Assim, ocorrem materiais de caráter coluvionar em meio aos solos, em sua maior parte material concrecionário milimétrico e eventualmente seixos e camadas cascalhentas em meio aos perfis de solo, indicando a ocorrência de truncamento do perfil. Porém, a oeste deste planalto baixo, fora dos limites da área de estudo, ocorrem planaltos mais baixos que este, definindo desta forma seu comportamento como denudacional.

P3 - PLANALTOS MÉDIOS (1000 - 1200M) Planaltos de grande expressão na porção leste da área de estudo, apresentam dissecação moderada, podendo ser delimitados pelo sistema de colinas associadas, havendo áreas com colinas em forma de meia-laranja e áreas com colinas alongadas. As colinas em forma de meia-laranja ocorrem mais próximas do contato do embasamento cristalino com as rochas sieníticas (que englobam em alguns casos gnaisses e paragnaisses), já as colinas alongadas ocorrem em áreas cristalinas.

A nordeste ocorre o planalto em que se localiza a cidade de Botelhos, apresentando alta dissecação em alto estrutural com formação de solos profundos e bem drenados. Estes solos apresentam caráter oxídico, com a formação de materiais vermelhos (predomínio de óxido de ferro - hematita).

Há planaltos médios também na porção noroeste, próximos ao planalto de Divinolândia, com dissecação moderada a forte em terrenos cristalinos.

P4 - PLANALTOS ALTOS (1200 - 1400M) Os principais planaltos altos da área de estudo correspondem às paleoplanícies inseridas no maciço, apresentando comportamento denudacional após soerguimentos, o que lhes conferem a classificação como planaltos altos fracamente dissecados. Representam o nível de base no interior da estrutura alcalina.

Sendo que o $\mathrm{P} 4.2 \mathrm{~b}$ adjacente (a leste) à planície de inundação da Represa Águas Claras está mais baixo em relação aos demais planaltos no interior do maciço, tendo sido este o último estágio da paleolagoa que deve ter sido drenada para o Rio Pardo, apresentando expressivos volumes orgânicos soterrados. Estes volumes orgânicos correspondem a Organossolos cuja gênese está associada a paleoambientes lacustres.

Outros planaltos altos de menor extensão assemelham-se a morros residuais cobertos por material cascalhento no interior do maciço.

A baixa dissecação e a ausência de estruturação do relevo em formas definidas como colinas, por exemplo, indicam que os depósitos superficiais são muito re- 
centes e que não se percebe reativação tectônica atual no sentido de definir partições nestas unidades fisiográficas, o que permite, de certa forma, uma datação relativa destas paleoplanícies e a reconstrução da evolução da paisagem. Ocorrem pequenos planaltos altos com dissecação moderada inseridos nestas paleoplanícies.

Não ocorrem estas unidades fisiográficas em terrenos cristalinos, um planalto alto próximo ao Planalto de Divinolândia situa-se no contato entre o embasamento cristalino e as alcalinas. Assim, os planaltos altos são feições características da região fisiográfica do planalto de Poços de Caldas.

\section{P5 - PLANALTOS MUITO ALTOS E SUPERFÍCIES} RESIDUAIS (ACIMA DE 1400M) São áreas restritas representadas pelas maiores elevações na área de estudo, que em alguns pontos ultrapassam 1600 metros de altitude: $1636 \mathrm{~m}$ de altitude no Pico do Gavião em Andradas (SW), 1679m no maciço da Pedra Branca em Caldas (SE) e 1636m na Serra de São Domingos, em Poços de Caldas (N). Nestes planaltos, situados no contato entre os sienitos e as encaixantes, a dissecação varia de fraca a moderada e devido às altas declividades, são freqüentes as exposições de maciços rochosos associados a Neossolos saprolíticos.

Um planalto muito alto localizado fora do contato está situado bem ao centro da área de estudo, sendo resultante de diques e sills provenientes de uma intrusão alcalina de menor intensidade que definiu a formação de uma caldeira vulcânica que atualmente encontra-se extremamente dissecada. Esta região sofreu a ação do processo de hidrotermalismo e concentra grande parte das jazidas de minerais radioativos existentes na área de estudo.

Outro planalto muito alto é o de Divinolândia, já em domínio de materiais cristalinos, predominantemente gnaisses e migmatitos, com grande controle estrutural definindo a formação de colinas alongadas e drenagem em forma de treliça. A forte dissecação e a posição de alto topográfico favoreceram a concentração de minério de bauxita nesta unidade fisiográfica.

P6 - TALUDES Os taludes (ou vertentes) foram estudados intensamente pelos geomorfólogos, como resultado tem-se numerosos estudos sobre a origem e sobre a nomenclatura destas formas de relevo (Daniels \& Hammer 1992).

Neste estudo, consideraram-se como taludes as superfícies inclinadas do terreno associadas a depósitos de detritos (Guerra 1969). Na área de estudo, os taludes constituem importante feição fisiográfica, uma vez que são numerosos, embora não tenha sido possível representar todos os taludes existentes na escala deste trabalho.

A forma e a declividade dos taludes são fatores que interferem no potencial erosivo. Quanto à forma dos taludes, são possíveis muitos arranjos complexos. Porém, para fins de análise, os formatos dos taludes foram agrupados em quatro categorias, representadas pela figura 8 .

$\mathrm{Na}$ área de estudo, predominam os taludes mis-

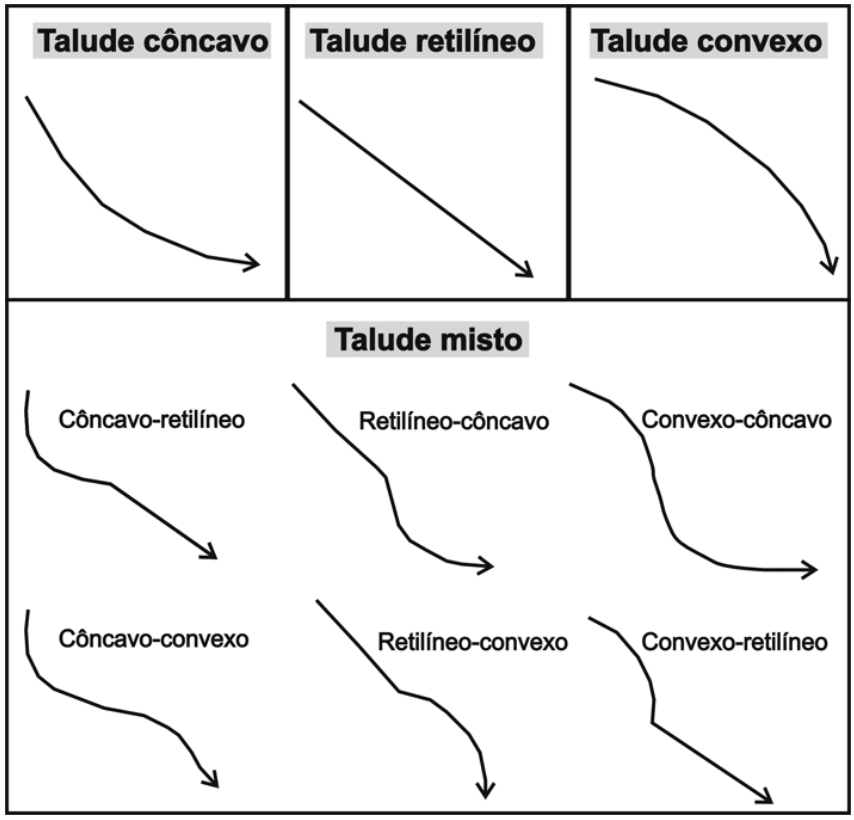

Figura 8 - Formas dos taludes. Adaptado de BIRKELAND, 1984.

tos, sendo mais freqüentes os arranjos entre porções convexa e retilínea. Os taludes côncavos muitas vezes são estreitos e restritos às chamadas "galerias" de drenagem que ocorrem em meio às vertentes convexas ou retilíneas de maior extensão.

Os depósitos de detritos que ocorrem associados aos taludes inseridos em paisagens planálticas na área de estudo são constituídos por material coluvional de transporte gravitacional. O colúvio se origina de deslizamentos, desmoronamentos, fluxos terrosos e desprendimentos. Em conseqüência, depositam-se a curta distância de sua fonte, e os fragmentos não chegam a modificar suas arestas angulares, sua distribuição é caótica sem estratificação, dando origem a uma topografia irregular, inclinada a ondulada (Villota 2005 e Saadi 1998).

$\mathrm{Na}$ área de estudo o material coluvional é formado por fragmentos de rochas alcalinas ou cristalinas (dependendo do embasamento). Também são comumente encontrados os fragmentos de lateritas e latossolos exumados, que ao se depositarem e intervindos os fatores bioclimáticos podem promover a retrogênese nos perfis de solos. É importante salientar que estes materiais coluvionais muitas vezes recobrem unidades de origem fluvial e que não estão restritos aos taludes, mas também aos planaltos. Estes materiais, ao se depositarem, permitem o desenvolvimento de solos a partir de material regolítico originalmente alóctone.

Deve-se destacar a ocorrência de material coluvional bem característico distribuído em todo o interior e nas bordas do maciço. Este material é formado por fragmentos de rochas alcalinas e lateritas, ambos com formato angular a sub-arredondado e tamanho centimétrico, dificilmente ultrapassando 10 centímetros quando expostos na superfície, conforme mostrado pela figura 9. A presença deste material contendo concreções laterí- 
ticas de tamanho milimétrico a centimétrico soterrando materiais discordantes foi considerada uma evidência de sua origem alóctone.

Leques coalescentes Os "leques coalescentes" ou depósitos de piemonte são formados pela ocorrência sucessiva de cones de deslizamento e outros depósitos coluvionares na base de uma vertente (Villota 2005). $\mathrm{Na}$ área de estudo, estes leques são muito freqüentes e podem ser reconhecidos através de fotointerpretação por sua localização e pelas formas arredondadas, porém, em grande parte dos casos, estes leques já se encontram incorporados aos planaltos e/ou aos taludes.

Embora nos cones possa não haver seleção de materiais, por serem formados muitas vezes por movimentos rápidos e de grande energia, em alguns casos, quando o transporte é mais lento, torna-se possível visualizar a sequência de sobreposição de deslizamentos por diferenças na textura. Por vezes, a diferenciação é possível através da análise da composição e granulometria do depósito, demonstrando diferentes pulsos de deposição em um relevo policíclico (Saadi 1998).

Desta forma, é possível definir que em geral os solos superficiais das paisagens planálticas são constituídos por materiais alóctones, cujas evidências marcantes são as camadas de cascalhos e concreções formadas por fragmentos de rochas e lateritas ou latossolos exumados. Estes materiais recobrem perfis de solo que foram truncados por processos erosivos e ao receberem depósitos, sofrem um rejuvenescimento, favorecendo a retrogênese e a ressilicificação destes materiais (Fig. 10), definindo a ampla ocorrência de Neossolos Regolíticos e de Cambissolos Háplicos verificada na área de estudo.

Paisagens Aluviais As unidades fisiográficas que caracterizam as paisagens fluviais, aluviais e lacustres são as "planícies de inundação", podendo ser delimitadas na área de estudo pela presença de elementos morfológicos como terraços, diques marginais, áreas alagáveis e canais abandonados. Estes elementos foram avaliados durante a fotointerpretação e em campo, porém não foi possível representá-los na escala de apresentação.

As planícies de inundação foram divididas em planície "atual" e "paleoplanície". As planícies de inundação atual (A1) correspondem às áreas que são banhadas por canais atuais, apresentando os depósitos inconsolidados cenozóicos que as delimitam. A falta de estruturação destes depósitos faz com que se apresentem nas imagens com uma textura lisa e uniforme, fracamente dissecada, facilitando a sua delimitação. $\mathrm{Na}$ área de estudo estão associadas ao terraço fluvial da Represa da Graminha (extremo norte da área), ao terraço e lagoas marginais do Ribeirão das Antas (parte central do maciço). No extremo sudoeste da área, nos limites do município de São João da Boa Vista, os planaltos baixos levemente dissecados (P1.1) encontram-se associados a planícies de inundação da bacia hidrográfica do Rio Moji-Guaçu.

As paleoplanícies de inundação foram soerguidas e não apresentam o comportamento agradacional

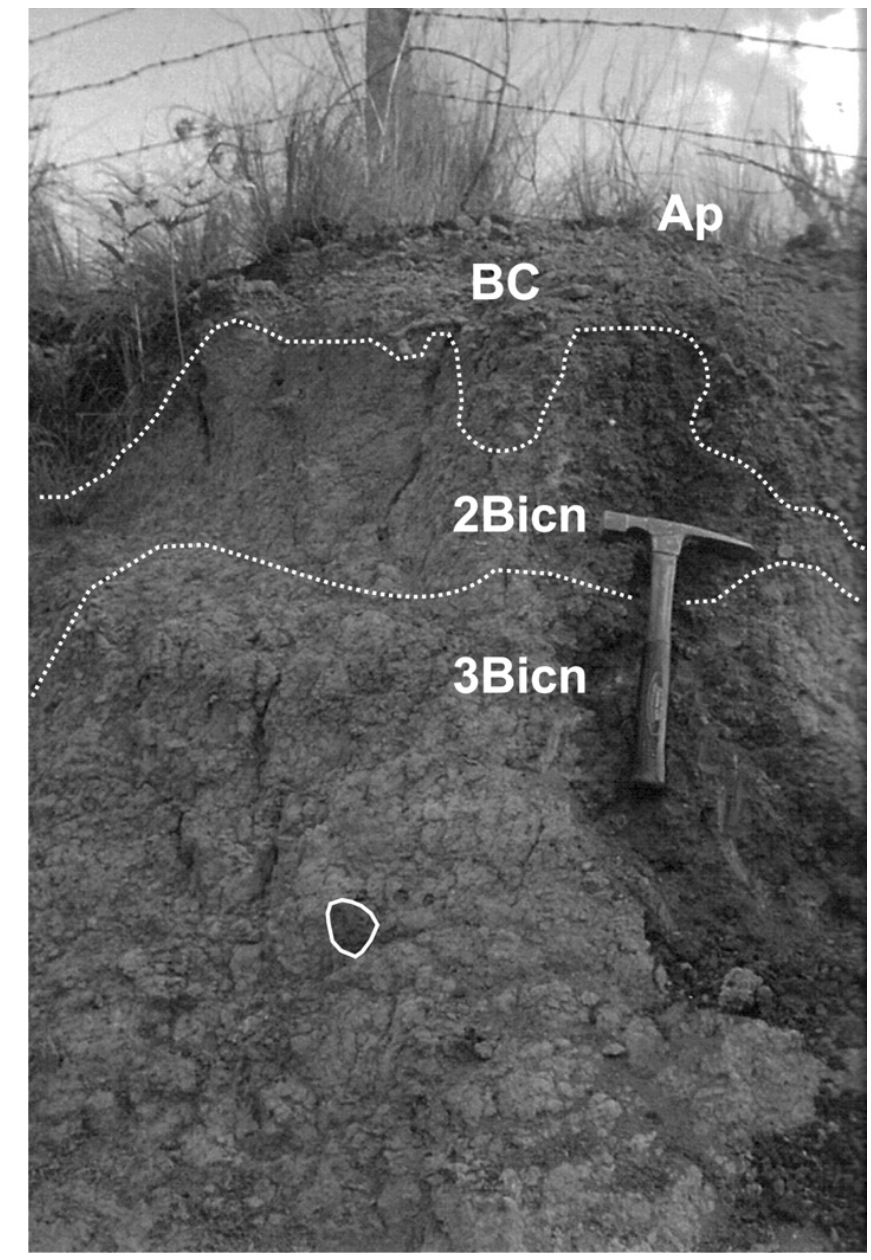

Figura 9 - Perfil de solo com volumes coluvionais, evidenciando processo de transporte e truncamento do perfil pré-existente. Coordenadas UTM x: 342496; y: 7570275 Datum Córrego Alegre; $1291 \mathrm{~m}$ de altitude. Ap - horizonte A perturbado, BC-horizonte subsuperficial com predomínio de características de horizonte $B e$ algumas características de horizonte $C, B i$-incipiente desenvolvimento do horizonte $B, c n$ - presença de concreções. Prefixos numéricos são usados para denotar descontinuidades. Segundo IBGE (2005).

que possuíam no passado, representando a transição entre planície atual e planalto. Apresentam remanescentes de unidades fisiográficas típicas de ambientes fluviais, como terraços escalonados, diques marginais e paleocanais ou paleolagoas abandonadas.

As paisagens podem ser datadas de forma relativa segundo os critérios muito antigo/antigo/subrecente/recente/subatual/atual (Barbosa et al. 2005), desta forma as paleoplanícies que ocorrem na área de estudos foram consideradas como planícies de inundação subatuais (A2).

As planícies de inundação atual (A1) encontradas no interior do maciço associam-se ao Rio das Antas, no centro-sul da área de estudo, abrangendo a Represa de Águas Claras, onde se origina o Rio das Antas e na porção noroeste, ainda associada a este rio. Também as planícies de inundação subatuais estão associadas 


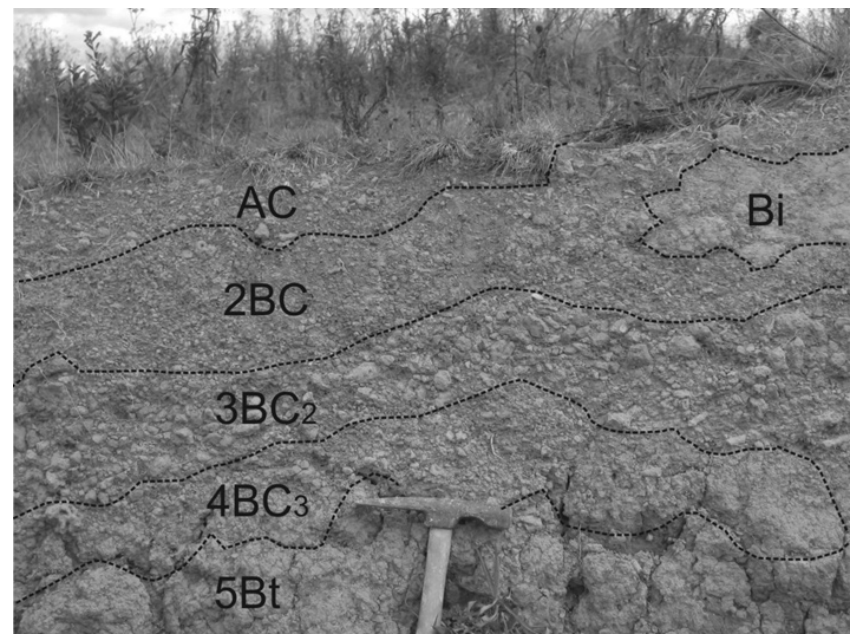

Figura 10 - Perfil de solo policíclico, evidenciando a ocorrência de diversos episódios de deposição de material gravitacional. O perfil mostrado situa-se no topo de um planalto alto (Coordenadas UTM x: 338406, y: 7580833, Datum Córrego Alegre, zona 23S, altitude: $1392 m)$. AC-horizonte subsuperficial com predomínio de características do horizonte A e algumas características do horizonte $C, B t-$ designa relavante concentração de argila. Sufixos numéricos são usados para subdivisão de horizontes principais (IBGE 2005).

ao Rio das Antas, sendo que nestas planícies ocorrem lagoas marginais temporárias que dificultam o uso da terra, mas apresentam importante papel ecológico na manutenção dos ecossistemas típicos de áreas alagáveis. As paleoplanícies apresentam terraços que foram soerguidos e comportam-se atualmente como pequenos planaltos, delimitados por taludes de forma e extensão variável (Moraes \& Jiménez-Rueda 2005b).

As planícies de inundação atual que ocorrem na porção sudoeste, na bacia hidrográfica do rio Mogi-Guaçu, possuem grande contribuição arenosa, o que confere ao solo boa textura em conjunto com as argilas.

Ao norte da área de estudo, uma planície atual é representada pela Represa da Graminha, em que o principal contribuinte a leste é o Rio Pardo e a oeste, o Rio Lambari (chamado de Rio das Antas em sua montante). Há também planícies menores próximas à cidade de Botelhos, sendo uma atual e uma subatual. Uma análise superficial das imagens de satélite indica que na bacia do Rio Pardo ocorre erosão mais intensa pela alta concentração de sólidos em suspensão nestes drenos em comparação com os da bacia do Rio Lambari.

Todas estas planícies apresentam canais abandonados e paleolagoas de pequena extensão que se tornaram muito ricas pela decomposição química dos minerais e pela retenção de boa parte da riqueza química lixiviada dos morros e encostas adjacentes (Setzer 1956).

Os solos associados às paisagens aluviais apresentam tipicamente volumes gleicos e materiais orgânicos enterrados. Na parte central do maciço alcalino, estes horizontes orgânicos enterrados $(\mathrm{Ab})$ representam as turfas e outros materiais formados em decorrência de uma maior área de atuação da paleodrenagem caudalosa, possivelmente associada a ambiente paleolacustre na planície do Ribeirão das Antas.

CONCLUSÕES Através da análise fisiográfica, foi possível estabelecer a ocorrência de dois grandes grupos de paisagens na região do planalto de Poços de Caldas, sendo as paisagens planálticas (tectônicas) e paisagens aluviais.

A divisão dos planaltos segundo a altimetria e o grau de dissecação permitiu o entendimento dos processos morfogenéticos particulares de cada trecho da área de estudo, facilitando o reconhecimentos dos padrões de solos destas paisagens.

Os solos nestas paisagens podem ser considerados como desenvolvidos a partir de materiais regolíticos alóctones, com presença de cascalho e concreções formadas por lateritas exumadas e fragmentos de rochas em um relevo policíclico e jovem. Constituem os Neossolos e Cambissolos que se encontram recobrindo perfis de solos que foram soterrados, predominantemente Latossolos e Argissolos. Estes materiais gravitacionais ocorrem nos planaltos de diferentes altimetria, inclusive no topo dos planaltos altos e muito altos.

Nas paisagens aluviais, os solos típicos apresentam volumes gleicos e material orgânico enterrado, indicando por vezes uma paleodrenagem mais densa que a atual.

Agradecimentos Ao CNPq pela concessão de bolsa de doutorado à primeira autora (Processo 141469/2004-8). À Gláucia Liberalli pela correção do resumo em inglês. Ao Leandro Letti pelo auxílio na elaboração e ajuste dos mapas. Ao Eymar Sampaio pelo auxílio com as técnicas de geoprocessamento.

\section{Referências}

Almeida Filho R. \& Paradella W.R. Estudo do maciço alcalino de Poços de Caldas através de imagens Landsat com ênfase em mineralizações radioativas. Dissertação de Mestrado, Instituto Nacional de Pesquisas Espaciais, São José dos Campos, SP. (INPE-112 TPT/065), 143p. Disponível em: http://urlib.net/sid. inpe.br/iris@1912/2005/07.15.22.28.26. Acesso em 17/09/2008.
Barbosa O.A., Bertani L.A., Fernandez F.R.H., Mendoza R.P. 2005. Analisis fisiografico para el levantamiento pedológico semidetalhado. Revista Brasileira de Engenharia Agrícola e Ambiental, 9(2):191-198.

Botero P.J. 1978. Fisiografia y estudios de suelos. Bogotá, Colômbia: Centro Interamericano de Fotointerpretación, $100 \mathrm{p}$.

Camara G., Souza R.C.M., Freitas U.M. 1996. SPRING: In- 
tegrating remote sensing and GIS by object-oriented data modelling. Computers \& Graphics, 20(3):395-403.

Casseti V. 2007. Introdução à Geomorfologia. Disponível em http://www.funape.org.br/geomorfologia/cap1/index.php. Acesso em 01/06/2007.

Cavalcante J.C., Cunha H.C., Chieregati L.A., Kaefer L.Q., Rocha J.M., Daitx E.L., Coutinho M.G.N., Hama M., Yamamoto K., Drumond J.B.V., Rosa D.B., Ramalho R. 1977. Projeto Sapucaí: relatório final-Geologia. São Paulo: Companhia de Pesquisa de Recursos Minerais, v.1, 615p.

Christofoletti A. 1973. A unidade morfoestrutural do planalto de Poços de Caldas. Not. Geomorf., Campinas, 13(26): $77-85$.

Daniels R.B., Hammer R.D. 1992. Soil geomorphology. New York: John Wiley \& Sons, 236p.

Ellert R. 1959. Contribuição à geologia do maciço alcalino de Poços de Caldas. Bol. Fac. Fil. Ciên. Letras USP, São Paulo, 237(18):5-63.

Guerra A.T. 1969. Dicionário geológico-geomorfológico. Rio de Janeiro: Fundação IBGE, 440p.

GLOBAL MAPPER LCC. 2005. Global Mapper. Disponível em: http://www.globalmapper.com/. Acesso em 10/05/2007.

Goosen D. 1967. Aerial photointerpretation in soil survey. Soils-Bulletin n.6. Roma, Itália: Food and Agriculture Organization of the United Nations, 65p.

Goosen D. 1971. Physiography and soils of the Llanos Orientales, Colombia. Enschede: Publications of the International Institute for Aerial Survey and Earth Sciences (ITC), 199p.

INSTITUTO BRASILEIRO DE GEOGRAFIA E ESTATÍSTICA (IBGE) 1972. Cartas do Brasil. SF-23-V-C-VI-4, $S F-23-V-D-I V-3, S F-23-V-C-V I-2, S F-23-V-D-I V-1, S F-$ 23-Y-B-I-1, SF-23-Y-A-III-2. Escala 1:50.000.

INSTITUTO BRASILEIRO DE GEOGRAFIA E ESTATÍSTICA (IBGE) 2005. Manual técnico de Pedologia. $2^{\mathrm{a}}$ ed. Manuais técnicos em Geociências, n.4, Rio de Janeiro: IBGE, 300p.

INSTITUTO GEOGRÁFICO AGUSTÍN CODAZZI (IGAC) 2007. Disponível em: http://www.igac.gov.co:8080/ igac_web/contenidos/home.jsp. Acesso 25/09/2007.

Jiménez-Rueda J.R., Nunes E., Mattos J.T. 1993. Caracterização fisiográfica e morfoestrutural da Folha São José de Mipibu, RN. Geociências, São Paulo, 12(2):481-491.

Mattos J.T., Jiménez-Rueda J.R., Ohara T., Mendes M.L.B., Santana M.A. 2002. Critérios para mapeamento de classes de risco a erosão de solos em imagem TM-LANDSAT. In: Anais Simpósio Latinoamericano de Percepción Remota, 9, Cochabamba-Bolívia. Disponível em http:// www.selper.org/. Acesso 20/09/2008.

Melo M.S., Stein D.P., Ponçano W.L., Bistrichi C.A. 1993. Neotectônica da área do Alto Rio Pardo (SP e MG). Revista do Instituto Geológico, 14(2):27-38.

Miranda E.E. (coord.) 2005. Brasil em Relevo. Campinas: EMBRAPA Monitoramento por Satélite. Disponível em: http://www.relevobr.cnpm.embrapa.br. Acesso em 01/04/2007.
Moraes F.T., Jimenez-Rueda J.R. 2005a. Caracterização morfoestrutural do município de Poços de Caldas, MG, visando ao estabelecimento de zonas geoambientais. In: Simpósio Brasileiro de Sensoriamento Remoto, 12, Goiânia, Anais, p.3837-3841.

Moraes F.T. \& Jimenez-Rueda J.R. 2005b. Importância de estudos fisiográficos no planejamento municipal: exemplo do Jardim Botânico de Poços de Caldas, MG. Geociências, São Paulo, 24(3):255-266.

Rizzini C.T. 1979. Tratado de fitogeografia do Brasil: aspectos sociológicos e florísticos. $1^{a}$ ed. São Paulo: HUCITEC, Editora da Universidade de São Paulo, $2^{\circ}$ vol., $374 \mathrm{p}$.

Saadi A. 1998. Modelos morfogenéticos e tectônica global: reflexões conciliatórias. Geonomos. 6(2):55-63.

Setzer J. 1956. A natureza e as possibilidades do solo no vale do Rio Pardo entre os municípios de Caconde, SP e Poços de Caldas, MG. Revista Brasileira de Geografia, Rio de Janeiro, 3:3-37.

Soares P.C. \& Fiori A.P. 1976. Lógica e sistemática na análise e interpretação de fotografias aéreas em geologia. Noticia Geomorfológica, 16(32):71-104.

Souza A.A. \& Jiménez-Rueda J.R. 2007. Análise fisiográfica e morfoestrutural no reconhecimento de padrões de solos no município de Porto Velho, RO. In: INPE, Simpósio Brasileiro de Sensoriamento Remoto, 13, Florianópolis, Anais, p. 6981-6985.

Suertegaray D.M.A. 2003. Terra: feições ilustradas. Porto Alegre: Editora da UFRGS, 263p.

Theodorovicz A., Theodorovicz A.M.G., Cantarino S.C. (coord.) 2002. Atlas Geoambiental das Bacias dos Rios Mogi-Guaçu e Pardo, SP: subsídios para o planejamento territorial e gestão ambiental. São Paulo: CPRM Serviço Geológico do Brasil, Coordenadoria de Planejamento Ambiental, 77p.

Thomaz Filho A. \& Rodrigues A.L. 1999. O alinhamento de rochas alcalinas Poços de Caldas-Cabo Frio (RJ) e sua continuidade na cadeia Vitória-Trindade. Revista Brasileira de Geociências, 29(2):189-194.

Tricart J. 1977. Ecodinâmica. Rio de Janeiro: IBGE, 97p.

Valeton I., Schumann A., Vinx R., Wieneke M. 1997. Supergene alteration since the upper Cretaceous on alkaline igneous and metasomatic rocks of the Poços de Caldas ring complex, Minas Gerais, Brazil. Applied Geochemistry, 12:133-154.

Veneziani P. \& Anjos C.E. 1982. Metodologia de interpretação de dados de sensoriamento remoto e aplicações em geologia. São José dos Campos: INPE, 54 p.

Villota H. 1992. El sistema CIAF de clasificación fisiográfica del terreno. Revista CIAF, 13(1):55-70.

Villota H. 2005. Geomorfología aplicada a levantamientos edafológicos y zonificación física de tierras. Bogotá: Instituto Geográfico Agustín Codazzi, 184p.

\section{Manuscrito ID 9516 Submetido em 09 de outubro de 2007 Aceito em 22 de junho de 2008 Sistema eletrônico de submissão}

